Animal Health Research Institute, Assiut, Egypt.

\title{
BACTERIOLOGICAL AND QUALITATIVE ANAL YSIS OF CAMEL'S URINE AND ITS RELATION TO URINARY BLADDER PATHOLOGICAL CHANGES
}

(With 5 Tables and 2 Figures)

By

G.F. KHAMIS; M.R. ABD ELLAH*;

NEVEEN A. ELNISR*; M. ABD ELMOETY**;

A.M. MANAA; A.A. AAMER* and M.M. ABDUL-HAFEEZ

* Dept. of Animal Medicine, Faculty of Veterinary Medicine, Assiut University 71526, Assiut, Egypt.

** Dept. of Biochemistry, Faculty of Medicine, Sohag University

(Received at 7/4/2009)

التحليل الوصفي والبكتيري للبول وعلاقته بالتغيرات الباثولوجية للمثانة البولية في الجمال

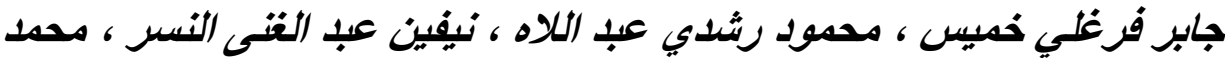

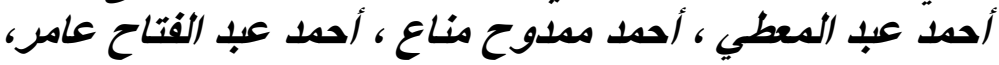
محمد محمد عبل الحفيظ مدوح ، أحل

هدفت هذه الدراسة إلى التعرف على أنواع التغير ات الباثولوجية للمثانة البولية في الجمال

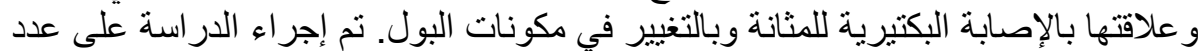

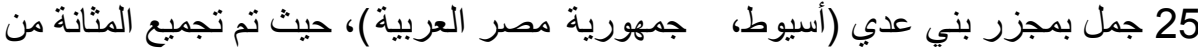

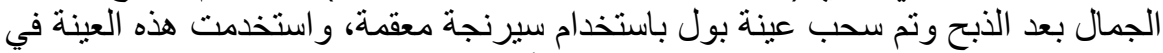

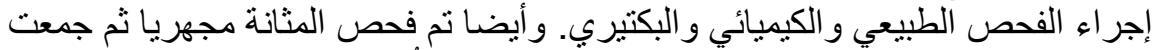

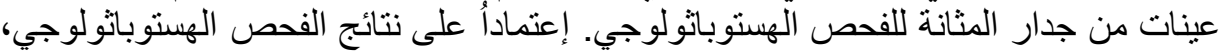

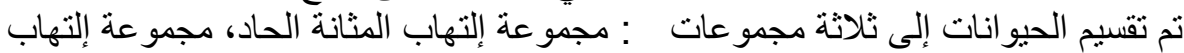

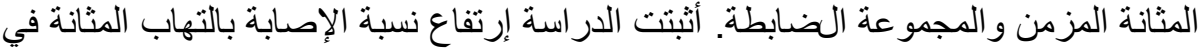

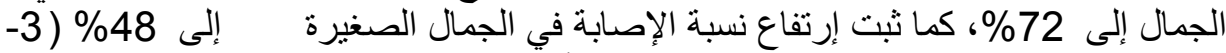

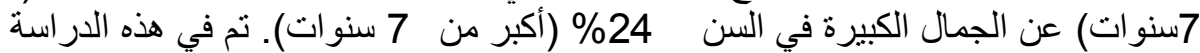

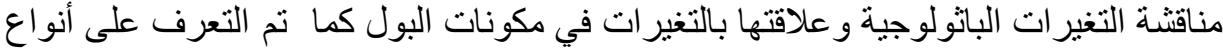

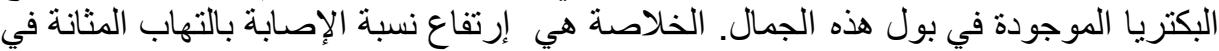

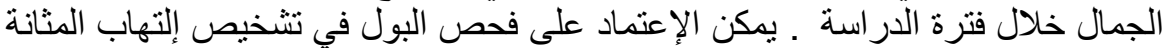

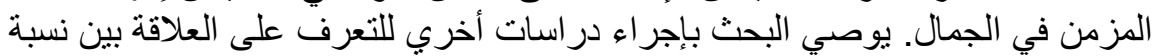
الإصابة بإلتهاب المثانة البولية في الجمال وفصول السنة. 


\section{SUMMARY}

The goal of the present study was to screen for urinary bladder affections in camels and correlate it with physicochemical, microscopical, bacterial and pathological changes. A total number of 25 male camels (3-12 years old) were subjected to study. Animals were slaughtered in Bani Adi slaughter house (Assiut, Egypt) during the period from February to May 2009. The urinary bladder was collected under complete aseptic conditions from each slaughtered animal just after evisceration. Urine samples were drawn using sterile syringe and used for both conventional urine analysis and bacteriological examination. An incision was made in the bladder and then it was examined macroscopically for presence of any pathological affection. A part from the bladder wall was kept in neutral buffered formalin for histopathological examination. According to the histopathological findings, camels under investigation were classified into three groups; acute cystitis group (n: 10), chronic cystitis group (n: 8) and control group (n: 7). Seventy two percentages of camels were found suffering from cystitis; out of them, 48\% aged 3-7 years old and $24 \%$ were above 7 years old. The relationships between pathological changes of the bladder and urine analysis were discussed. The bacteriological examination revealed isolation of Staphylococcus sp. (54.54\%), Corynebacterium sp. (27.27\%) and E. coli sp. (18.18\%) from the camel's urine. In conclusion, incidence of cystitis is higher in young camels than older ones. Urine analysis is helpful in diagnosis of chronic cystitis. Since the incidence of cystitis was rather high in studied period, further studies are required to elucidate the relationship between the season and cystitis in camel.

Key words: Bacteriology, cystitis, camel, histopathology, urine analysis.

\section{INTRODUCTION}

The urinary tract may be regarded as a specialized ecosystem in which urine continuously produced by the kidneys is intermittently voided through the urethra, its behavior in health and during infective process is determined by anatomical and functional factors. The bacterial flora of the urethra and pre-urethral area may also play a part in resistance and susceptibility to infection. The composition of urine in part determines the rate of bacterial growth in the urinary tract (William et al., 1998). 
Cystitis and urethritis are more common in the female camel because of a shorter urethra and the possibility of retrograde invasion by bacteria (Fowler, 1999), the author added that, the most important predisposing factors for cystitis are uretrolithiasis, bladder paresis and urine stagnation. The bacterial infection cause cystitis mainly come from ascending or descending route or may also occur by expansion from neighboring organs (Sastry, 1999). In some cases both acute and chronic cystitis showed no bacterial isolation. This phenomenon may be due to the destruction of the causative microorganisms by inflammatory reaction in the urinary bladder and hence no microorganisms had isolated. This had been confirmed by Mahanty and Singh (1970) and Hassan et al. (1991).

Urine analysis is one of the most important diagnostic tests that can help to localize disease, to determine causes of discolored urine and to identify inflammatory diseases of the urinary system (Pugh, 2002). The present study aimed to screen urinary bladder affections in camels and correlate it with physicochemical, microscopical, bacterial and pathological changes.

\section{MATERIALS and METHODS}

\section{Animals}

A total number of 25 male camels (3-12 years old) were subjected to study, animals were slaughtered in Bani Adi slaughter house (Assiut, Egypt) during the period from February to May 2009.

\section{Samples}

The urinary bladder were collected from each slaughtered animal after evisceration, urine samples were drawn using sterile syringe and divided into two parts; one part was used for physicochemical and microscopical urine analysis and the other part used for bacteriological examination, both the bladder and urine samples were transported to the laboratory in ice bag.

\section{Urine analysis}

Urine samples were examined physically, chemically using test strips (Medi-Test Combi 10® SGL, Macherey- Nagel, Germany) and microscopically according to Coles (1986).

\section{Bacteriological examination}

For bacterial enrichment, urine samples were inoculated into nutrient broth, overnight incubated at $37^{\circ} \mathrm{C}$. From the incubated tubes, loopfulls were streaked onto the surface of both blood agar with $5 \%$ 
sheep blood and MacConkey agar (Oxoid). The inoculated plates were incubated aerobically at $37^{\circ} \mathrm{C}$ for 24 hours. The suspected colonies were identified morphologically by Gram's stain and biochemically confirmed according to Quinn et al. (1994), using catalase activity, coagulase test

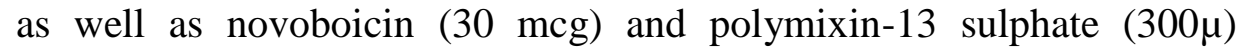
sensitivity tests for identification of Staphylococcus sp.

\section{Pathological examination}

The bladder was examined macroscopically for presence of any pathological affection and then a part from the bladder wall was preserved in neutral buffered formalin (10\%) and used for histopathological examination. For histopathological examination; the specimens were fixed in $10 \%$ formalin solution, washed in tap water and dehydrated in alcohol, cleared in methyl benzoate and embedded in paraffin. Paraffin sections of $5 \mu$ thick were prepared and stained with hematoxylin and eosin according to Bancroft and Stevens (1982).

\section{Statistical analysis}

Data from cystitis group (specific gravity, $\mathrm{pH}, \mathrm{RBCs} / \mathrm{HPF}$, WBCs/HPF) were compared with those from control camels using one way ANOVA followed by Dunnett test (post-hoc analysis, $\mathrm{p}<0.05$ ). Data were expressed as Mean $\pm \mathrm{SD}$, Statistical analysis was conducted using SPSS 16.0 for windows (SPSS, Chicago, USA).

\section{RESULTS}

According to the histopathological findings, camels under investigation were classified into three groups; acute cystitis group (n: 10), chronic cystitis group (n: 8) and control group (n: 7).

\section{Age of camels}

As shown in table 1 , there were $72 \%$ of camels suffered from cystitis, out of them $48 \%$ were 3-7 years old and $24 \%$ above 7 years old.

\section{Bacteriological examination:}

The following bacterial species were isolated from camel's urine, Staphylococcus epidermidis, Staphylococcus saprophyticus, Staphylococcus aureus, Corynbacterium sp. and E-coli sp. (Tables 4 and 5).

\section{Pathological findings}

\section{Acute cystitis}

Grossly; the affected urinary bladder was edematous and congested with areas of haemorrhages (Table 2 and Fig. 1). Microscopically; the urinary bladder showed vascular degeneration. 
Severe congestion was observed in their submucosal, intermuscular and serosal blood vessels with leucocytic infilteration (neutrophils and lymphocytes) around these blood vessels. The lamina propria was edematous and has a diffuse neutrophilic infilteration. These leucocytic infilteration was also found in the muscular layer (Fig. 2)

\section{Chronic cystitis}

Grossly; the wall of the bladder was thickened and pale in color (Fig. 1). Microscopical examination showed desquamation of the epithelial layer, hypertrophy of the muscular layer with focal and in some cases diffuse intermuscular aggregation mainly lymphocytes and macrophage cells. Severe proliferation of the tunica externa of the serosal blood vessels, which infiltrated with the inflammatory cells, mainly macrophage cells (Fig. 2).

\section{Urine analysis}

Urine analysis for cases with acute cystitis revealed the presence of traces of protein, microscopical examination revealed significant increases in RBCS $8.43 \pm 3.45 / \mathrm{HPF}$ and in pus cells $4.00 \pm 1.00 / \mathrm{HPF}$ (Table 3).

Urine from cases with chronic cystitis was whitish, turbid and with strong urineferous odor, there was a significant increase in the urine specific gravity $1.021 \pm 0.003$, with presence of protein and blood. Microscopical examination revealed the presence of clumps of transional epithelial cells, significant increase in RBCS 55.7 $\pm 3.77 / \mathrm{HPF}$ and in pus cells $5.57 \pm 0.78$ /HPF (Table 3).

Tabel 1: Age of the examined camels in relation to urinary bladder affections.

\begin{tabular}{|l|c|c|c|c|}
\hline \multirow{2}{*}{ Age } & \multicolumn{2}{|c|}{ Normal } & \multicolumn{2}{c|}{ Cystitis } \\
\cline { 2 - 5 } 3-7 years & No. & $\%$ & No. & $\%$ \\
\hline Over 7 years & 6 & 24 & 12 & 48 \\
\hline Total & 1 & 4 & 6 & 24 \\
\hline
\end{tabular}


Table 2: Morphological findings and distribution of urinary bladder affections according to camel's age

\begin{tabular}{|c|c|c|c|c|c|}
\hline Disease & Morphological findings & $\begin{array}{c}\text { No. of } \\
\text { cases }\end{array}$ & $\begin{array}{c}\text { Percent } \\
\text { of cases }\end{array}$ & $\begin{array}{c}3-7 \\
\text { years }\end{array}$ & $\begin{array}{c}\text { Over 7 } \\
\text { years }\end{array}$ \\
\hline Acute Cystitis & $\begin{array}{l}\text { The affected urinary } \\
\text { bladder was edematous } \\
\text { and congested with areas } \\
\text { of haemorhages. }\end{array}$ & 10 & 40 & 7 & 3 \\
\hline Chronic cystitis & $\begin{array}{l}\text { The Wall of the urinary } \\
\text { bladder was thickened } \\
\text { and pale in color. }\end{array}$ & 8 & 32 & 5 & 3 \\
\hline
\end{tabular}

Table 3: Physical, chemical and microscopical findings in camel's urine

\begin{tabular}{|c|c|c|c|c|}
\hline & Parameters & Control group & Acute Cystitis & Chronic cystitis \\
\hline \multirow{4}{*}{$\begin{array}{c}\text { Physical } \\
\text { examination }\end{array}$} & Colour & $\begin{array}{c}\text { pale yellow - } \\
\text { yellow }\end{array}$ & $\begin{array}{c}\text { pale yellow - } \\
\text { yellow }\end{array}$ & whitish \\
\hline & Odour & Urineferous & urineferous & $\begin{array}{c}\text { strong } \\
\text { urineferous }\end{array}$ \\
\hline & Transparency & Clear & clear & turbid \\
\hline & Specific gravity & $1.013 \pm 0.003$ & $1.014 \pm 0.002^{\mathrm{NS}}$ & $1.021 \pm 0.003 * *$ \\
\hline \multirow{7}{*}{$\begin{array}{c}\text { Chemical } \\
\text { examination }\end{array}$} & $\mathrm{pH}$ & $8.43 \pm 0.53$ & $8.71 \pm 0.48^{\mathrm{NS}}$ & $8.85 \pm 0.37^{\mathrm{NS}}$ \\
\hline & Urobili & Normal & normal & normal \\
\hline & Nitrite & Negative & negative & negative \\
\hline & Protein & Negative & + & +++ \\
\hline & Glucose & Negative & negative & negative \\
\hline & Ketone & Negative & negative & negative \\
\hline & $\mathrm{RBCs}$ & Negative & + & +++ \\
\hline \multirow{4}{*}{$\begin{array}{l}\text { Microscopical } \\
\text { examination }\end{array}$} & $\mathrm{RBCs} / \mathrm{HPF}$ & $0.42 \pm 0.53$ & $8.43 \pm 3.45^{* *}$ & $55.71 \pm 3.77 * *$ \\
\hline & WBCs/HPF & $0.86 \pm 0.14$ & $4.00 \pm 1.00 * *$ & $5.57 \pm 0.78 * *$ \\
\hline & Epithelial cells & Negative & negative & $\begin{array}{c}\text { Transitional } \\
(+++)\end{array}$ \\
\hline & Crystals & Negative & negative & negative \\
\hline
\end{tabular}

$* *$ : significant $(\mathrm{p}<0.01)$

NS: Not significant 
Table 4: Bacteriological findings in urine of investigated camels

\begin{tabular}{|c|c|c|c|c|}
\hline \multicolumn{2}{|c|}{$\begin{array}{c}\text { Examined urine } \\
\text { samples }\end{array}$} & \multirow{2}{*}{$\begin{array}{c}\text { Negative for } \\
\text { bacteria }\end{array}$} & \multicolumn{2}{c|}{$\begin{array}{c}\text { Positive for bacteria } \\
\text { (No. 17) }\end{array}$} \\
\cline { 4 - 5 } Number & 25 & 8 & Single & Mixed \\
\hline Percent & 100 & 32 & 48 & 5 \\
\hline
\end{tabular}

Table 5: Bacterial strains isolated from urine samples

\begin{tabular}{|l|c|c|}
\hline \multicolumn{1}{|c|}{ Bacterial species } & Number & Percent \\
\hline Staphylococcus aureus & 1 & 4.55 \\
\hline Staphylococcus epidermidis & 7 & 31.82 \\
\hline Staphylococcus saprophyticus & 4 & 18.18 \\
\hline Corynbacterium sp. & 6 & 27.27 \\
\hline E-coli sp. & 4 & 18.18 \\
\hline Total & 22 & $100 \%$ \\
\hline
\end{tabular}



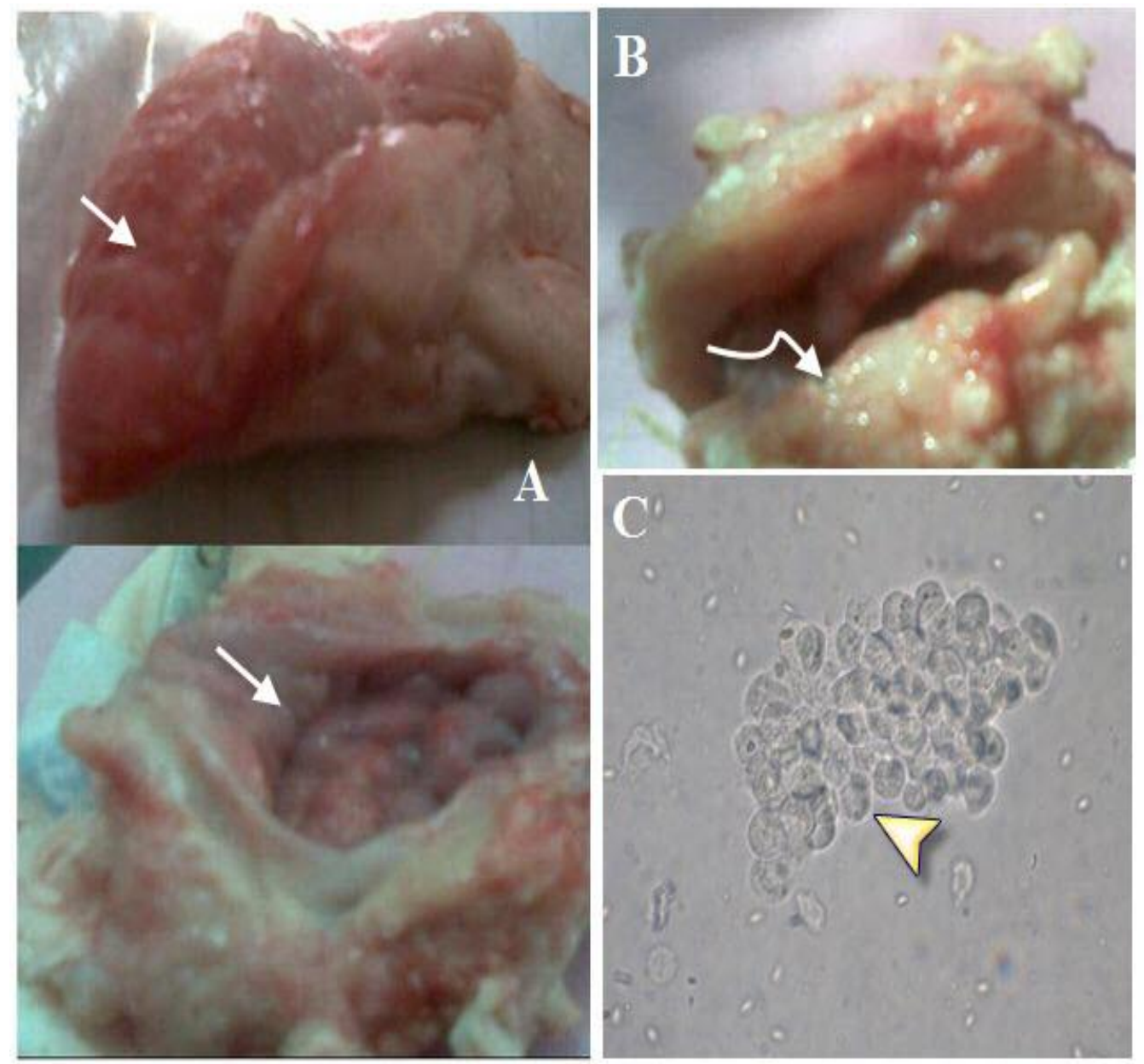

Fig. 1: Urinary bladder of camel. (A) Acute cystitis showing congested mucosa (arrow). (B) Chronic cystitis increase thickness of the muscular layer (curved arrow). (C) Urine sediment in chronic cystitis showing collection from transitional epithelial cells (arrow head) and RBCs (x40). 


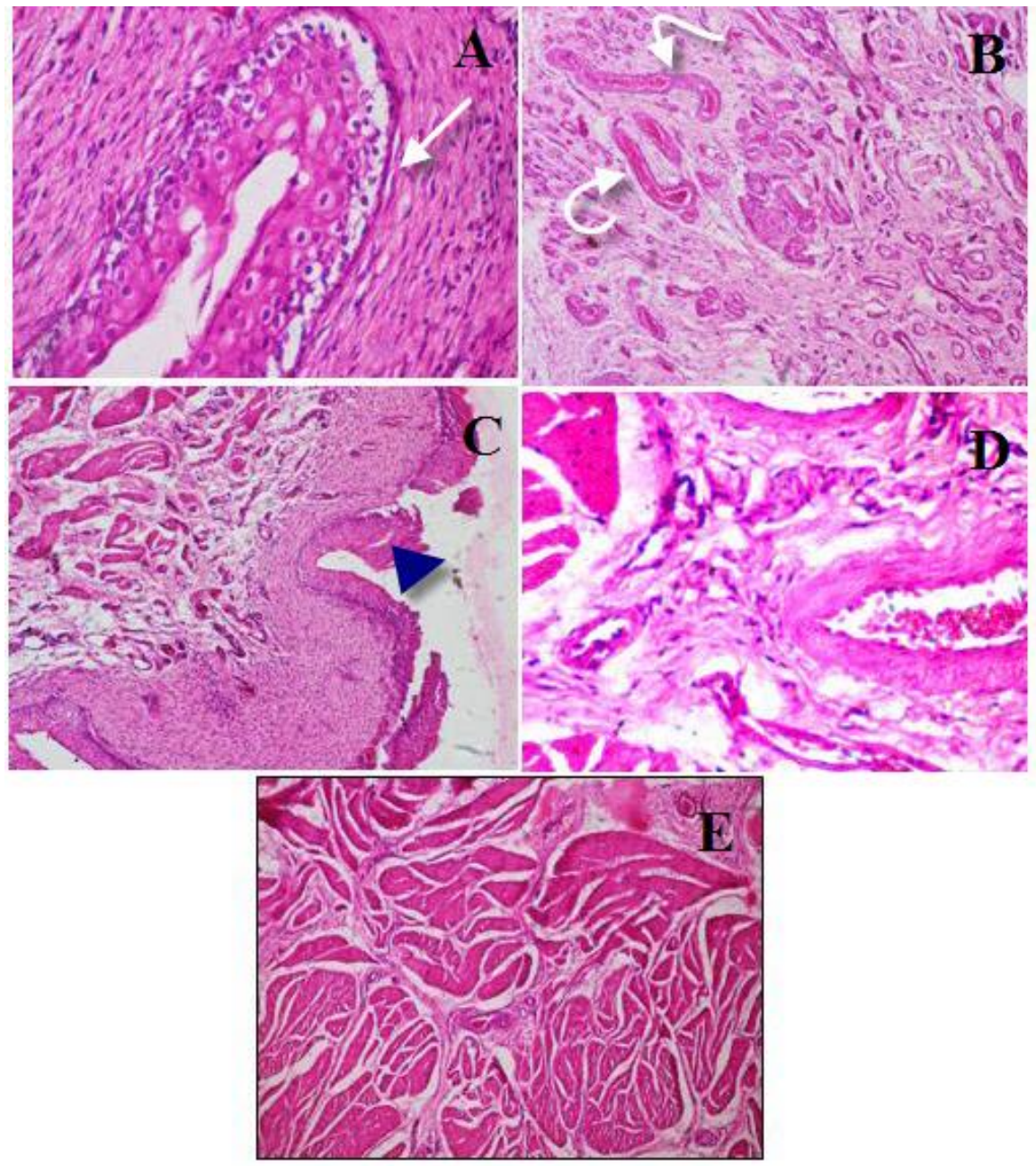

Fig. 2: Photomicrograph showing urinary bladder in camel cystitis. (A) Acute cystitis showing vacuolar degeneration of the epithelium of the urinary bladder (arrow) (H\&Ex40). (B) Acute cystitis showing congestion of mucosal and submucosal blood vessels (curved arrow) (H\&Ex10). (C) Chronic cystitis showing desquamation of the epithelial lining and congestion of mucosal blood vessels (arrow head) (H\&Ex10). (D) Chronic cystitis showing blood vessel surrounded with proliferating connective tissue and leucocytic infiltration (H\&E x40). (E) Chronic cystitis showing muscular hypertrophy with connective tissue proliferation and leucocytic infiltration (H\&E x 10). 


\section{DISCUSSION}

In the present study the incidence of cystitis was high in investigated camels (72\%), in addition, young camels (3-7 years old) were more susceptible (48\%) to cystitis than older one (24\%), higher incidence of cystitis may be attributed to the time of the year, as samples were collected during the rutting season, further investigation are required to confirm or exclude the relation between season and incidence of cystitis in camel.

Urine analysis by test strips in control camels are the same as reported by Fowler (1999), who stated that normal urine sample of camel is yellow to amber in color, has a $\mathrm{pH}$ ranged from 7-8.5 and specific gravity $1.010-1.048$. Control group in our study has a $\mathrm{pH} 8$ 8.5 , specific gravity 1.010-1.015 and yellow colored urine with urineferous odor.

Bacteriological examinations revealed that $32 \%$ of examined urine samples were negative for bacterial isolation. The rest $68 \%$ showed positive results either in single form $48 \%$ or in mixed form $20 \%$ (Tabel 4). Bacterial isolated strains were tabulated in Table (5). Rather than the $32 \%$ negative bacterial samples, commensals represented high proportion $(68.17 \%)$ of the isolated strains where Staphyloccal coagulase negative (Staphylococcus epidermedis and Staphylococcus saprophyticus) resembled $49.99 \%$ and E-coli resembled $18.18 \%$ despite of great percentage of cystitis $72 \%$. The urine of female camels above 5 years age may contain Enterococcus faecalis, Staphylococcus aureus, Escherichia coli, Micrococcus sp, Gemella marbillarum as bacterial natural flora without any pathological lesions. By scanning electron microscope, camel's urine affected the morphological structure of some pathogens such as; MERSA, E-coli and Pasteurella aeruginosa (Aishea Ba-hatheq, 2006). There was weak correlation between cystitis and bacterial isolation - in the present study - as we failed to isolate any bacterial agents form some cystic cases, while it was detected bacterial existence in some of control group. According to the above mentioned premise, it seems that cystitis in the present slaughtered camels might be attributed mainly to etiological parameters other than bacterial infections.

According to the pathological findings, both acute and chronic cystitis were found in the investigated camels. Grossly, our result was agreed with Mc Gavin and Zachary (2007), as they said that the vascular damage in case of acute cystitis predisposes to haemorrhage, leakage of 
fibrin. Also Hassan et al. (1991), Damjanov and Linder (2000) and Carlton and Mc Gavin (2001) also found that the urinary bladder in case of acute cystitis was congested. Microscopically our results were explained by Carlton and Mc Gavin (2001) and Mc Gavin and Zachary (2007) as they said that cystitis occur when the bacteria are able to overcome the normal defense mechanisms and adhere to or invade the urinary bladder mucosa, once bacteria gain access to the lamina propria they cause vascular damage. The lesion in the muscular layer was mentioned and agrees with Divers (1996).

Abnormal findings in the urine sample in cases suffered from acute cystic were increase the RBCs in the urine sediment and slight increase in the pus cells, results of urine analysis are in accordance with the above histopathological findings. Urine analysis is not sufficient for diagnosis of acute cystitis in camels.

Grossly, the picture of the urinary bladder with chronic cystitis was similar to those mentioned by Hassan et al. (1991) and Damjanov and Linder (2000) as they found that the urinary bladder in case of chronic cystitis has thick walls and may show trabeculation as a result of smooth muscle hypertrophy. Microscopically: the desquamation of the epithelial layer was seen also by Hassan et al. (1991), Sastry (1999) and Mc Gavin and Zachary (2007). Also we found hypertrophy of the muscular layer with focal and diffuse intermuscular leucocytic aggregation, this result was similar to those obtained by Abdel Baset (1991), who found fibrosis and focal leucocytic aggregation in the tunica muscularies of the camel's urinary bladder suffered from chronic cystitis.

The urine in case of chronic cystitis was turbid, whitish in color due to the presence of large numbers of transitional epithelial cells, RBCS and Pus cells (Fig. 1). The $\mathrm{pH}$ of urine increased due to presence of bacteria, and urine specific gravity reached up to 1.021 , which is higher than control. Urine analysis in chronic cystitis is the same as reported by Fowler (1999). The results indicated that urine analysis is sufficient for diagnosis of chronic cystitis in camels and correlated well with the histopathological findings.

In conclusion, incidence of cystitis is higher in young camels than older one. Urine analysis is helpful in diagnosis of chronic cystitis. The incidence of cystitis was high during February to May, further studies are required to elucidate the relationship between the season and cystitis in camel. 


\section{REFERENCES}

Abdel-Baset, T.M. (1991): Pathological studies on the relation between skin affections and the pathological changes in kidneys, suprarenal and urinary bladder in camels. Thesis, Faculty of Veterinary Medicine (Banha branch), Zagazeg University.

Aishea, M. Ba-hatheq (2006): Antimicrobial effect of camel's urine on some pathogenic bacteria. Thesis for Ph.D. Faculty of Science- Biology Department. Geddah, Suadia Arabia.

Bancroft, J.D. and Stevens, A. (1982): Theory and Practice of Histopathological Techniques, 2nd ed., Churchill Livingstone, Edinburgh, pp: 134.

Carlton, W.W. and Mc Gavin, M.D. (2001): Thomson's Special Veterinary Pathology. $2^{\text {nd }}$ Ed., Mosby Publisher, pp: 234-244.

Coles, E.H. (1986): Veterinary Clinical Pathology. $4^{\text {th }}$ Ed., Saunders Comp. Philadelphia, London, Toronto. pp: 221.

Damjanov, I. and Linder, J. (2000): Pathology, A Color Atlas. St. Louis, Mosby Publisher.

Divers, T.J. (1996): Diseases of the Renal System. In: Large Animal Internal Medicine (Smith, B.P. editor). $2^{\text {nd }}$ Ed., St Louis, Mosby Publisher.

Fowler, M.E. (1999): Medicine and Surgery of South American Camelids: Llama, Alpaca, Vicuña, Guanaco. $2^{\text {nd }}$ Ed., Wiley-Blackwell, pp: 340.

Hassan, H.A.; Bahgat, A.M.; Hafez, M.H.; Moursi, A.E and El attar, E.R. (1991): Pathological study on kidney and urinary bladder affections in camels at Sharkia province. M. V. Sc. Thesis, Faculty of Veterinary Medicine, Zagazeg University.

Mahanty, G.C. and Singh, C.M. (1970): Pathogenic feature of focal non supurative interstitial nephritis in buffaloes. Indian Vet. J. 47: 391396.

Mc Gavin, M.D and Zachary, J.F. (2007): Pathologic Basis of Veterinary Diseases. $4^{\text {th }}$ Ed., Mosby Publisher, pp: 686-691.

Pugh, D.G. (2002): Sheep and Goat Medicine. $1^{\text {st }}$ Ed., W. B. Saunders Company, pp: 290-303.

Quinn, P.J.; Carter, M.E.; Markey, B. and Carter, G.R. (1994): Clinical Veterinary Microbiology. Walfe Publishing, Mosby Year Book, Europe Limited.

Sastry, G.A. (1999): Veterinary Pathology. $6^{\text {th }}$ Ed., Part II, CBS Publishers and distributors, pp: 395-396.

William, J.; Hausler, J.R. and Max Sussman (1998): Topley and Wilson's Microbiology and Microbial infection. $9^{\text {th }}$ Ed. Vol. (3), Oxford University Press Inc. New York, pp: 602-610. 